\title{
Erosion and accumulation flood landforms in Sázava River in spring 2006
}

\author{
MAREK KŘÍǏEK \\ Charles University in Prague, Faculty of Science, \\ Department of Physical Geography and Geoecology
}

\begin{abstract}
This article deals with channel bars, flood accumulations of floodplain and bank scours as the most important geomorphologic effects of the spring flood in Sázava River in 2006. The article deals particularly with its spatial distribution with regard to the channel position and weirs. Relation between basic characteristics of sediments of these channel bars is surveyed. Spatial and statistical analyses were done in ArcGIS 9.2 and STATISTICA 8 Standard based on input data from field geomorphological mapping after the flood in 2006, it follows that there is a relation between spatial distribution of channel bars and flood accumulations in floodplain. There is also a relation between channel bars and bank scours. It emerged that spatial distribution of channel bars, flood accumulations in floodplain and bank scours is uneven and connected to weirs whose immediate effective sedimentary influence reaches in Sázava River to $60 \mathrm{~m}$ distance. Smaller channel bars connected to banks are typical for parts of river which are not influenced by weirs. Channel bars can be used for placement prediction of flood accumulations in floodplain.
\end{abstract}

Key words: floodplain - flood accumulations - channel bars - bank scours - weirs - flood - Sázava River

\section{Introduction}

Floodplain is an exposed area where anthropogenic and fluvial (natural or anthropogenic influenced or accelerated) geomorphologic processes meet (e.g. Whittow, 1984; Collin, 1988; Huggett, 2003; Brierly, Fryirs, 2005; Kř́žek, 2007a). Overbank floods present decisive processes for channel formation (Hickin, 1983). Monitoring of erosion and accumulation fluvial processes in spatial (within and outside the channel) and time context enables prediction and insight of channel-floodplain geosystems' functioning (sensu Knighton, 1998; Lehotský, 2005). Floodplain sediments are controls on channel behavior (Schumm, Thorne, 1989). Effects of fluvial accumulation and erosion in channels and floodplains are mainly studied only in selected parts of rivers (e.g. Walling, He, 1998; Steiger, Gurnell, 2001; Hooke, 2003; Pierce, King, 2008). Discrete approach to research of fluvial accumulation and erosion effects together with change of type of channel bars depending on local channel morphology (sensu Zielinski, 2003) limits an evaluation of continual spatial dependences of channel bars and overbank accumulations (in longitudinal profile). Nicholas and Walling (1997), Walling and He (1998), Steiger and Gurnell (2001) dealt with prediction of flood sediment deposition in floodplains (rather in their cross- 
profiles) based on modeling of mean annual deposition rates. Czech geomorphology works which deal with geomorphologic effects of recent great floods (in 1997, 2002, 2006) concentrate more or less on the flood geomorphology effect inventory or they studied relation of the floods to anthropogenic channels' changes (Hrádek, 1999; Hrádek, 2005; Křǐžek, Engel, 2006).

The aim of this article is to characterize basic positional and qualitative characteristics of fluvial accumulation and erosion landforms which were created or were transformed during the flood in 2006 and to determine their mutual relations.

During springtime in 2006 snow melting on large areas in middle altitudes occurred which led to overflow of large number of rivers and resulting floods. Snow water storage was in total $446.3 \mathrm{mil}^{3} \mathrm{~m}^{3}$ in the whole catchment of Sázava River on $20^{\text {th }}$ March 2006 (Šercl et al., 2006). These spring floods caused bankfull of Sázava River accompanied by creation of fluvial erosion and accumulation landforms in its floodplain and its channel. The two-top flood culminated on $30^{\text {th }}$ March 2006 and maximum discharge of Sázava River was $536 \mathrm{~m}^{3} / \mathrm{s}$ in Nespeky, for comparison the mean annual discharge of Sázava River is $23.4 \mathrm{~m}^{3} / \mathrm{s}$ in Nespeky (Šercl et al., 2006).

The studied area, where the analysis of geomorphologic effects of the spring flood was elaborated, is formed by floodplain of Sázava River from its confluence with Losenický potok Brook in the upper part up to Pikovice where damming water of Vltava's cascade comes through (Fig. 1). A $183 \mathrm{~km}$ long section of floodplain was mapped during 27 days.

Sázava River is single-channeled, meandering stream with an irregular sinusoity. The valley of Sázava River is in the major part of the flow characteristic by its deep valley where difference in height of the valley bottom and its edge reaches up to

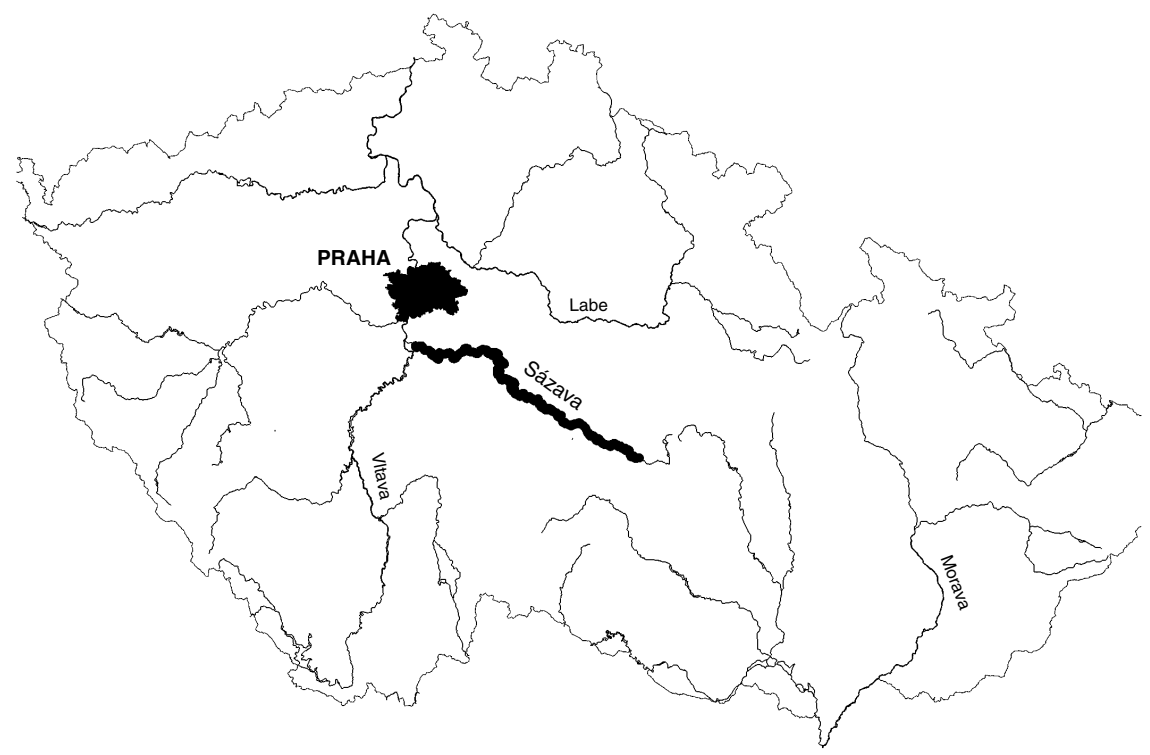

Fig. 1: Position of study area - Sázava River 
$200 \mathrm{~m}$. According to various authors (Balatka, Sládek 1962) approximately 4 alluvial terrace levels in convergent direction towards the flow exist here. The lowest and youngest terrace level is located 2-10 $\mathrm{m}$ above the valley bottom and the highest and oldest terrace level is situated in highs 72-126 m (Balatka, Sládek, 1962).

From the geological viewpoint the major part of Sázava River valley is developed on basement composed of granites and granodiorites of Middle-Bohemian pluton which are locally crossed by dikes of paleovolcanic and metamorphic rocks. Lithologic situation reflects into sandy sediments (as a result of granite weathering) which were transported and accumulated by Sázava River during the flood.

\section{Methods}

Geomorphologic mapping of geomorphologic effects of the spring flood in 2006 was executed in period of time from 7 May to 4 July 2006 and focused on floodplain (actually on bottom of Sázava River valley) and landforms which extend into it from surrounding valley slopes. Basic maps of the Czech Republic with scale $1: 10000$ (ČÚZAK) were basic documents for field mapping. The field mapping was executed according to unified legend created by M. Kř́žžek (Křižzek, 2006). Constituent parts of Sázava River were mapped and digitalized by 8 employees and students of Department of Physical Geography and Geoecology of Faculty of Science of the Charles University in Prague. The results obtained by the field workers were revised and completed by the author of this article; morphometrical and positional characteristics were set by GPS and laser range finder and clinometer MDL LaserAce-Hypsometer.

Tab. 1: Surveyed characteristics of selected landforms

\begin{tabular}{|c|c|}
\hline Landform & Attributes \\
\hline Alluvial fan & $\begin{array}{l}\text { Thickness: max. thickness (height difference between foot and top of this } \\
\text { landform) of its sediment in the floodplain }\end{array}$ \\
\hline Alluvial terrace & Height: height above the current floodplain \\
\hline Floodplain /borders/ & $\begin{array}{l}\text { Type: accumulation (1), transport (2) and erosive part (3) refers to floodplain only } \\
\text { not the channel }\end{array}$ \\
\hline $\begin{array}{l}\text { Flood accumulation } \\
\text { in the floodplain }\end{array}$ & $\begin{array}{l}\text { Type: sandy }(\mathbf{1}) \text {, gravel }(\mathbf{2}) \text {, combined }(\mathbf{3})+\text { Origin: date of origin if known, } \\
\text { e.g. } 2002 \text {, otherwise } 0\end{array}$ \\
\hline Bank scours & Origin: date of origin if known, e.g. 2002 , otherwise 0 \\
\hline Weir & Height: up to $1 \mathrm{~m} \mathrm{(1);1-2} \mathrm{m} \mathrm{(2);} \mathrm{above} 2 \mathrm{~m}(\mathbf{3})$ \\
\hline Bridge, footbridge & $\begin{array}{l}\text { Length }+ \text { Height above the bottom of the river-channel (maximal) + State: not } \\
\text { damaged }(0) \text {, damaged }(\mathbf{1}) \text {, destroyed }(2)\end{array}$ \\
\hline Bar & $\begin{array}{l}\text { Width of the river-channel: width of the channel in the locality of a bar }+ \\
\text { Location: }(\mathbf{1}-\mathbf{5}) \text { see fig. } 1+\text { Length + Width + Connection: without connection } \\
\text { to bank }(\mathbf{0}) \text {, connection to bank }(\mathbf{1})+\text { Material: sandy }(\mathbf{1}) \text {, gravel }(\mathbf{2}) \text {, combined } \\
(\mathbf{3})+\text { Gradation: without gradation }(\mathbf{0}) \text {, normal gradation }(\mathbf{1}) \text {, inverse gradation } \\
(\mathbf{2})+\text { Vegetation: without vegetation }(\mathbf{0}) \text {, grass }(\mathbf{1}) \text {, shrubs or trees }(\mathbf{2})\end{array}$ \\
\hline
\end{tabular}


The floodplain was defined in accordance with geomorphologic definition as flat accumulation plain along watercourse built from fluvial sediments; during floods it gets usually partly or completely flooded and its boarders were determined based on its different morphology (inclination of slopes) from valley slopes and other landforms (sensu Křížek, Hartvich, Chuman et al., 2006). These landforms and buildings located in floodplain and its surrounding were classified: alluvial fans, fluvial (alluvial) terraces, fluvial (flood) overbank accumulations in floodplain, bank scours, weirs, bridges and channel bars (Tab. 1; Křížek, 2006). Channel bars represent fluvial sediments in the river channel. Width of the river channel was measured for every bar (for corresponding part of channel where bar is situated). Its position within the channel was also determined. The channel was divided into 5 sections with the following cross-section profile orientation: section 1 lies near the left bank and section 5 lies near the right bank. In case a bar lies in more sections it was marked by rising numeral order of particular sections (e.g. 234). The channel bar length describes the size which is parallel to the water flow direction and the width is perpendicular to it. Other bars' feature was connection with banks (whether it is /e.g. lateral bar - sensu Brierley, Fryirs 2005/ or it is not connected with a bank). Psephite to psammite ratio was detected for each fluvial accumulation. From the grain size viewpoint the fluvial sediments were distinguished: gravel-cobbles (contain more than $25 \%$ of coarse grained /psephite/ clasts), sands (contain less than $10 \%$ of coarse grained /psephite/ clasts) and combined (contain 10-25\% of coarse grained /psephite/ clasts) (sensu Kukal, 1985). Gradation means sediments segregation and their sorting by size: normal gradation means that the fluvial material which builds the channel bar gets more fine-grained sediment in the downstream direction; inverse gradation means that fine-grained sediments are deposited first than coarse sediments (sensu Bridge, 2003); channel bars without gradation do not have apparent sorting. The last surveyed feature was channel bar cover by vegetation: vegetation free, partly covered by grass, with shrubs or trees. This characteristic describes stability, actually duration of existence of the channel bar.

Spatial information about landforms and their other characteristics were processed in ArcGIS 9.2 (ESRI 2003) with the use of extension - Spatial Analysis and then were statistically analyzed (one-way ANOVA) in program STATISTICA 8 Standard (StatSoft 2003). Densities of channel bars, flood overbank accumulations and bank scours were determined in GIS for cell size $100 \mathrm{~m}$ and radius $1000 \mathrm{~m}$. Distance relation between single landforms were determined with the use of buffering with $5 \mathrm{~m}$ step and conversion into the grid for cell size $5 \mathrm{~m}$. The first distances category of flood overbank accumulations from the channel (i.e. 0-25 m) was determined regarding to changes of channel width (from $7 \mathrm{~m}$ on the upper stream to $75 \mathrm{~m}$ on the lower stream of Sázava River). Centroids of flood accumulations substitute real areas of these landforms for mutual position relations between channel bars and flood overbank accumulations in the floodplain. This was done in order to limit error of multiple-choice matching of larger flood accumulations to more than one channel bar. For the same reason centroid was used to calculate density of flood overbank accumulations in the floodplain. 


\section{Results}

\section{Floodplain and flood accumulation landforms}

Floodplain of Sázava River is separated from other part of relief (e.g. from valley slopes or step of alluvial terrace) by an edge with more significant inclination change which appears in cross-section profile. Whereas surface of Sázava River floodplain has inclination to $2^{\circ}$, neighboring valley slopes have inclinations in range $7-90^{\circ}$, which is due to erosion valley of Sázava River cutting into the basement. In areas where alluvial fans of adjacent valleys reach floodplain of Sázava River the channel is being pressed away towards opposite bank which is usually accompanied by narrowing of floodplain

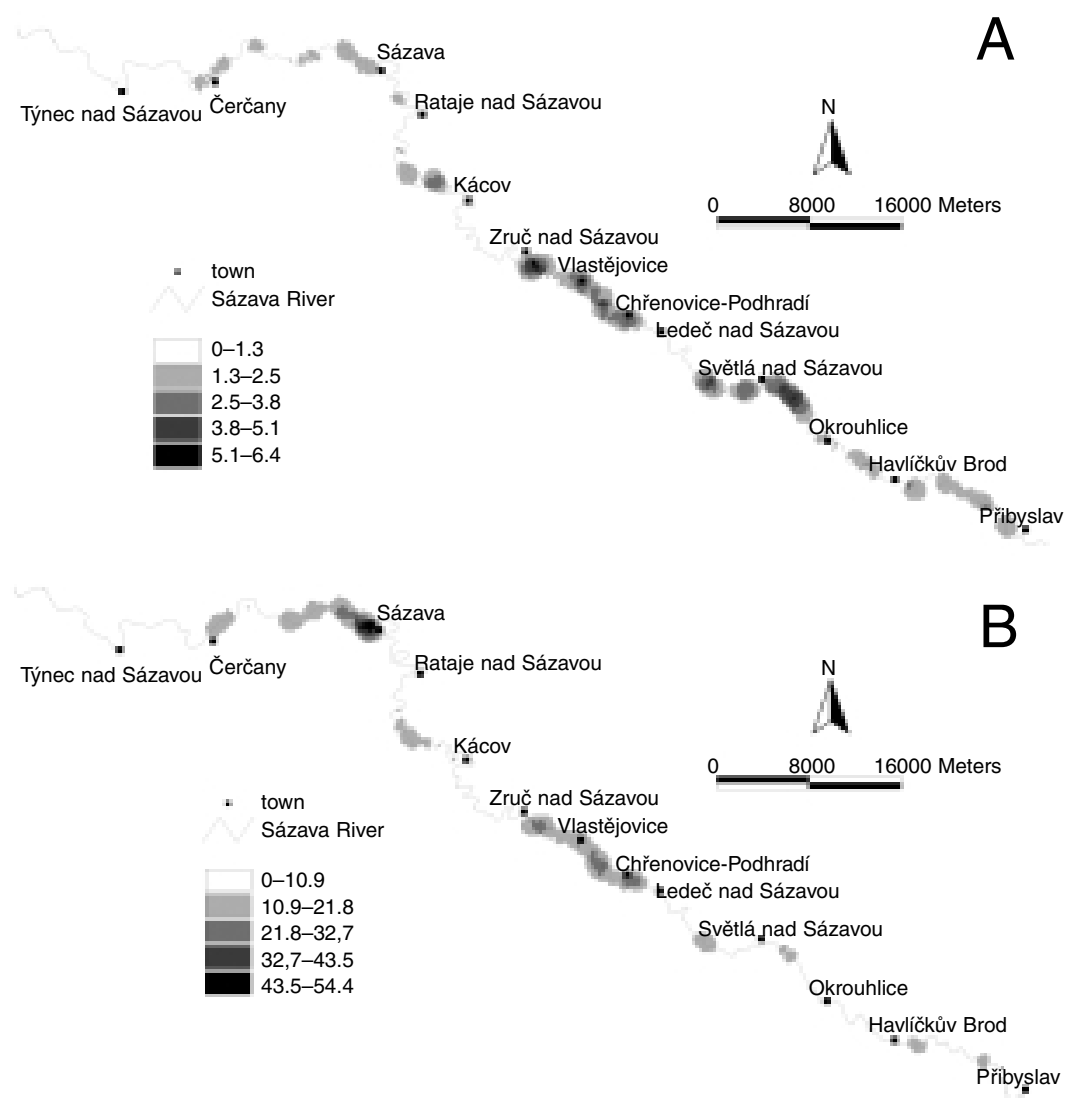

Fig. 2: Density of flood overbank accumulations in the floodplain. Density defines number of flood overbank accumulations per $1 \mathrm{~km}^{2}$ for radius $1000 \mathrm{~m}$. A - Each flood overbank accumulation in the floodplain is represented by its centroid; thus the density is calculated with respect to centroid of each flood overbank accumulation in the floodplain. B - Each flood overbank accumulation in the floodplain is represented by several points. Number of these points depends on the area of relevant flood overbank accumulation in the floodplain; thus the density is calculated with respect to area of each flood overbank accumulation in the floodplain 
width. Regarding the total length of Sázava River it can be stated that width of the studied part of floodplain is more or less constant, actually in the upper and middle part of Sázava River it increases very slowly in the direction of downstream. Further, in some areas in direction of downstream it gets more narrow (e.g. below Havlíčkův Brod) which is caused by geologic predisposition and also by anthropogenic impact into the floodplain, e.g. railway embankments. The average floodplain width is $115 \mathrm{~m}$ in the studied upper part of Sázava River, its range is from 20 to $389 \mathrm{~m}$. The average width of floodplain in the studied middle part of Sázava River is $121 \mathrm{~m}$, it ranges in interval from 42 to $432 \mathrm{~m}$. Generally we can say that variation from the average is not as big as it is in the studied upper part of Sázava River. The average floodplain width is $110 \mathrm{~m}$ in the lower part of the studied floodplain of Sázava River, however the variation of widths of floodplain is the smallest, boundary values are 70-167 m.

During the flood in spring 2006 the floodplain was completely inundated in some places, inundation occurred even outside the floodplain in some localities. Flood sediments found on feet of alluvial fans or on lower terrace steps, which lie out of the floodplain, prove it. In the studied part of floodplain of Sázava River there were found 262 sandy flood overbank accumulations ( $86 \%$ from total number), their total area is 102 ha (79.4\% from total area of all flood accumulations in the floodplain), 8 gravel-cobble flood overbank accumulations (3\%), their area is 1 ha $(0.7 \%$ from total area of all flood accumulations in the floodplain) and 28 combined flood overbank accumulations (9\%), their area is 25 ha $(19.4 \%$ from total area of all flood overbank accumulations) and 5 unrecognized flood accumulations (2\%), their area is 0.7 ha $(0.5 \%$ from total area of all flood accumulations in the floodplain). Mean thickness of these accumulations reaches 3-30 cm. Most of flood overbank accumulations can be found near Čerčany, below town Sázava, between Ledeč nad Sázavou and Zruč nad Sá-

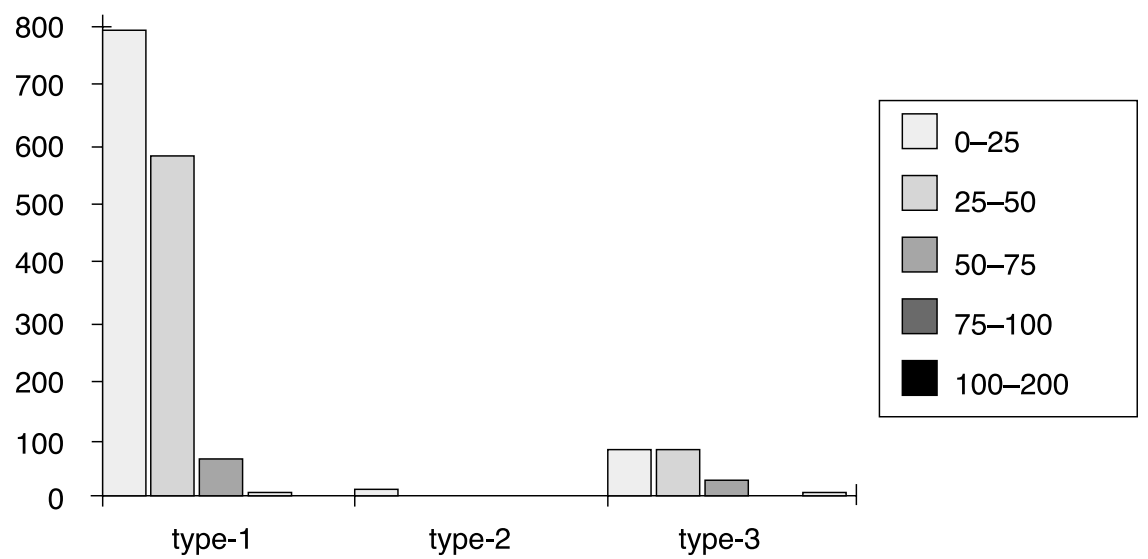

Fig. 3: Number of types of flood overbank accumulations regarding distance from the channel (midstream). Type 1 - sandy flood accumulations, 2 - gravel-cobble flood accumulations, 3 - combined flood accumulations. Category values $(0-25,25-50$ etc.) represent distances from midstream in meters. Each flood overbank accumulation in the floodplain is represented by several points - with respect to area of each flood overbank accumulation in the floodplain 


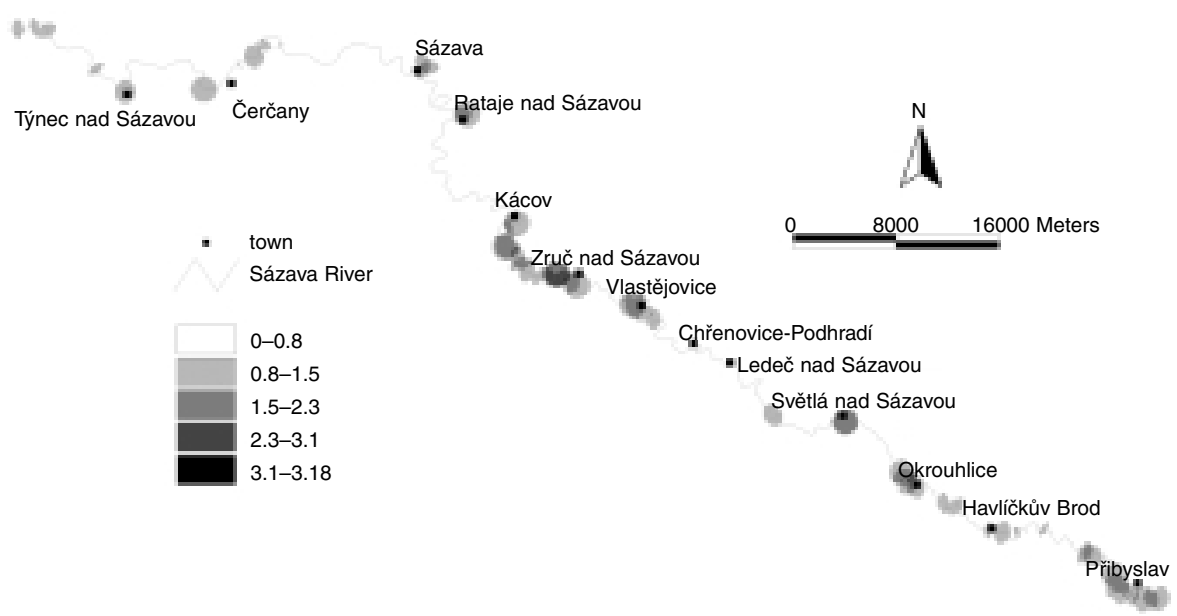

Fig. 4: Density of channel bars in Sázava River. Density represents number of channel bars per $1 \mathrm{~km}^{2}$ for radius $1000 \mathrm{~m}$

zavou, surroundings Světlá nad Sázavou and below Přibyslav (Fig. 2). The same picture shows evident conformity between number of flood overbank accumulations in floodplain and their areas. Concentration of flood sediments is the highest in immediate vicinity of Sázava River channel (Fig. 3), distances up to $25 \mathrm{~m}$ from midstream of the channel prevail and flood overbank accumulations which are distant above $75 \mathrm{~m}$ from midstream of the channel occur sporadically. Combined type of flood overbank accumulations has the most frequent distance from midstream in range 40-60 m. It is related to multiphase process of accumulation in middle part of floodplain where these landforms are situated only in these positions (ranges). Most (73\%) of flood accumulations can be found within $20 \mathrm{~m}$ from weirs.

147 channel bars were found in the studied part of floodplain in total, 27 (18\%) were sandy, $81(55 \%)$ gravel-cobble and $39(27 \%)$ combined sediment. From the viewpoint of gradation $119(81 \%)$ of channel bars without gradation were identified, $26(18 \%)$ with normal gradation and $2(1 \%)$ with inverse gradation. $82(56 \%)$ of channel bars were not connected with banks so they formed islands while $65(44 \%)$ were connected with banks. 64 (44\%) channel bars had no vegetation cover, grass was found on 55 (37\%) channel bars and shrubs or trees grew on 28 (19\%) of them. The highest densities of channel bars were in surroundings of Přibyslav, Okrouhlice, Světlá nad Sázavou, Vlastějovice and then between Zruč nad Sázavou and Kácov, Rataje nad Sázavou, Sázava, Čerčany, Týnec nad Sázavou and Čísovice (Fig. 4).

Channel bars are located mainly in vicinity of weirs (Fig. 5, 6), most of them can be found within $20 \mathrm{~m}$ from a weir then their number falls rapidly. Channel bars with normal gradation occur mostly in immediate vicinity of weirs, within distance up to $20 \mathrm{~m}$ then their number smoothly falls. On the contrary, channel bars without gradation are mainly located in distance up to $20-60 \mathrm{~m}$ from weirs, their minimal number is located in distance of 60-100 m. Channel bars with inverse gradation were found only in distance of 60-100 m from weirs. From the viewpoint of channel bars' position in channel, they 


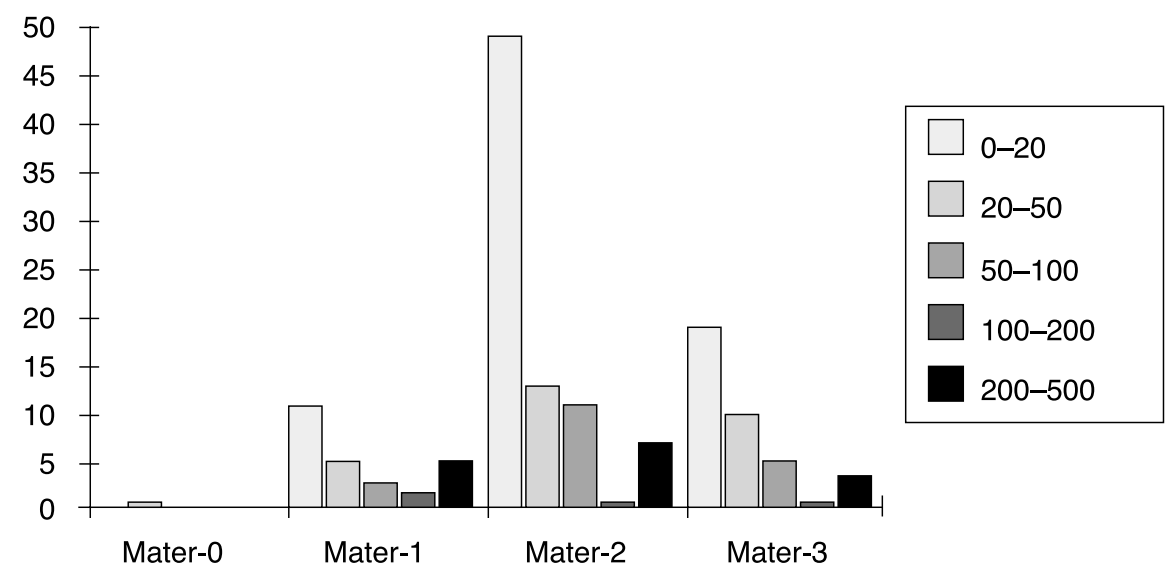

Fig. 5: Spatial distribution of channel bars regarding distance from weirs (in meters). Mater-0 ... nonspecified channel bars; Bars: Mater-1 ... sandy; Mater-2 ... gravel-cobble; Mater-3 ... combined

do not occur in channel sections 1 and 5 in immediate vicinity of weirs (up to $20 \mathrm{~m}$ ), they occur the most in distance bigger than $100 \mathrm{~m}$ from weirs, on the contrary central positions (channel sections: 2, 3, 4, 23, 34, 234) of channel bars (e.g. medial bars or transverse bars - sensu Brierley, Fryirs, 2005) occur usually up to $60 \mathrm{~m}$ from weirs. Most

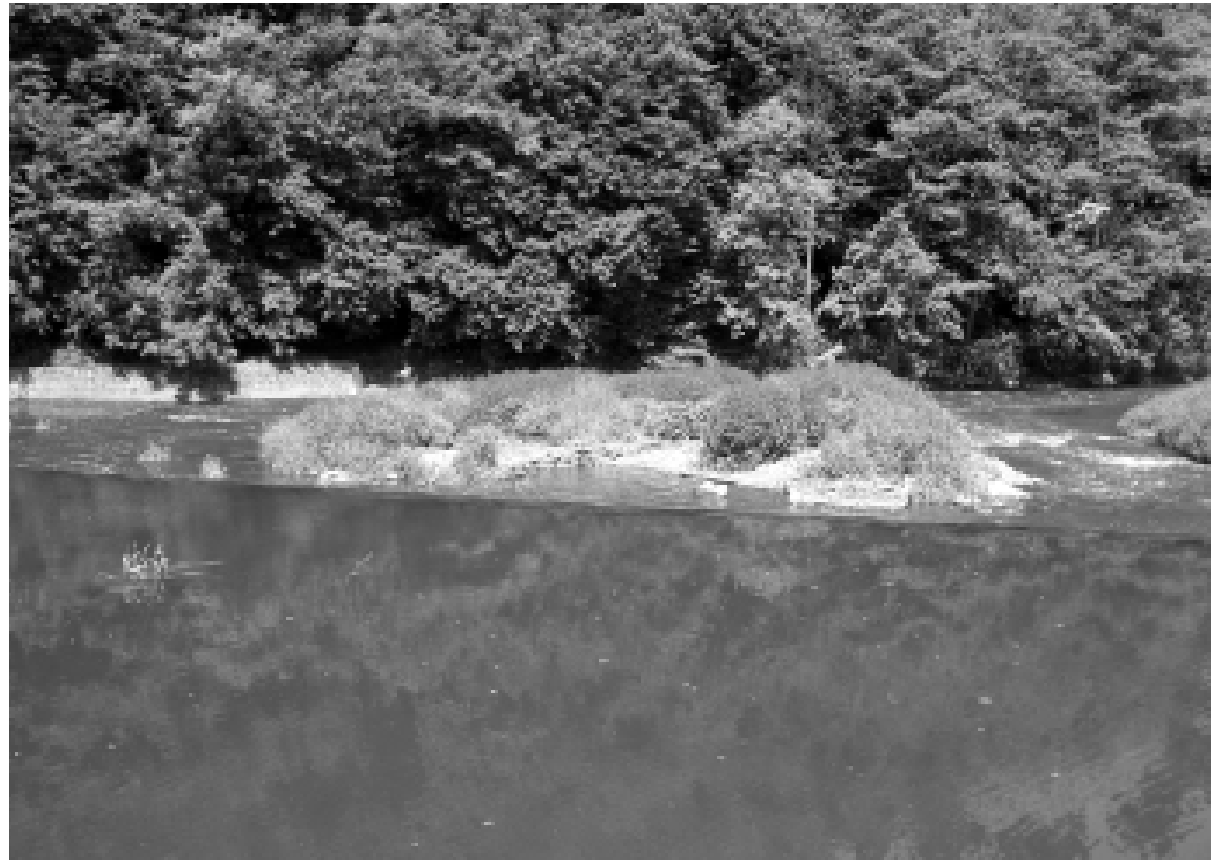

Fig. 6: Channel bar with grass cover bellow a weir near Chřenovice 
of channel bars connected with banks (lateral bars - sensu Brierley, Fryirs, 2005) are located in distances bigger than $100 \mathrm{~m}$ from weirs. Majority of large channel bars with width more than $5 \mathrm{~m}$ are located in distance of 20-60 m from weirs, contrary small bars with width up to $3 \mathrm{~m}$ are spread out more regularly with maximal occurrence in distance above $100 \mathrm{~m}$. Channel bars covered by grass, shrubs or trees or channel bars without vegetation cover can be found the most up to $60 \mathrm{~m}$ from weirs, only bars with shrubs and trees occur much less in immediate vicinity of weirs (up to $20 \mathrm{~m}$ ). Sandy and gravelcobble channel bars occur mostly in distances of 0-30 m from bank scours.

\section{Erosion flood landforms and function of anthropogenic landforms during the flood}

Erosion geomorphologic effects (or landforms) of the spring 2006 flood did not have such extend in floodplain of Sázava River as flood accumulation landforms. 176 bank scours in total length of $10359 \mathrm{~m}$ were found. The average length of bank scours is $59 \mathrm{~m}$ and the median is $30 \mathrm{~m}$. Bank scours reach the highest densities in the middle and upper part of the studied floodplain which means below Kácov, below Zruč nad Sázavou (Čížov), above Zruč nad Sázavou, below Ledeč nad Sázavou, between Světlá nad Sázavou and Přibyslav (Fig. 7). If floodplain sediments were washed away somewhere, it always occured on small areas related to narrowing of floodplain and mainly to surroundings of weirs (90\% of all bank scours are located up to $10 \mathrm{~m}$ from weirs). These are places where bankfull stream reaches higher speed. This narrowing, accelerating formation of erosion furrows in floodplain, is of natural origin (e.g. alluvial fan nearby Chřenovice-Podhradí) or of anthropogenic character in areas of narrowing of cross-section profile of channel and floodplain (e.g. behind the bridge below Havlíčkův Brod) (Fig. 8).

Although there are settlements, roads, railways and technical buildings in Sázava River floodplain, it is possible to say that it kept its natural form in basic features. Low

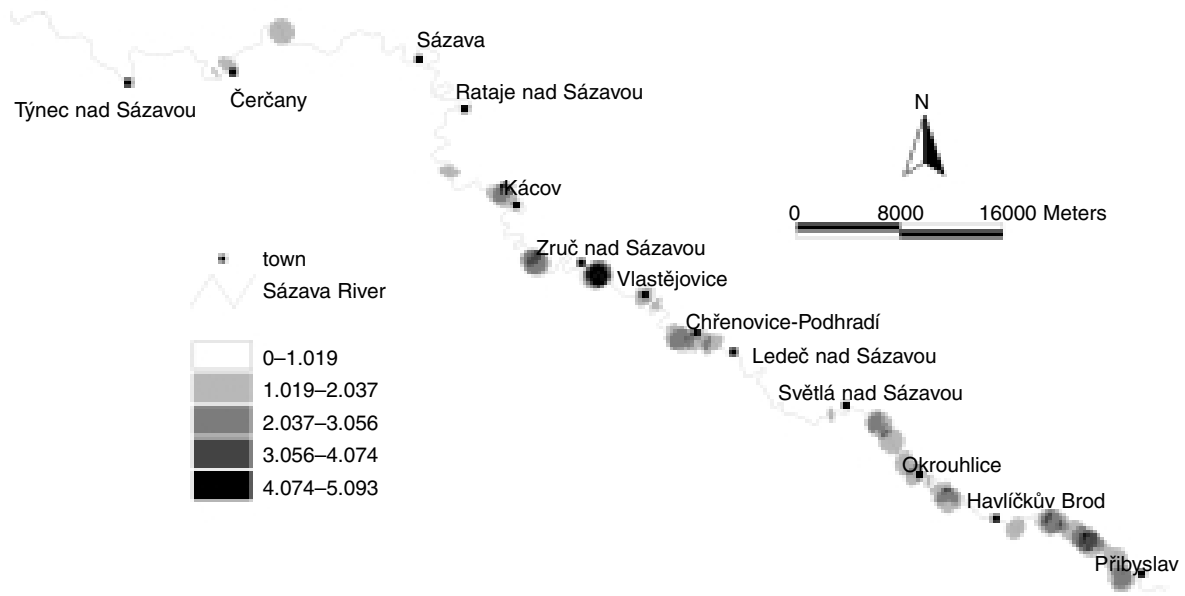

Fig. 7: Density of bank scours in Sázava River. Density represents number of bank scours per $1 \mathrm{~km}^{2}$ for radius $1000 \mathrm{~m}$ 


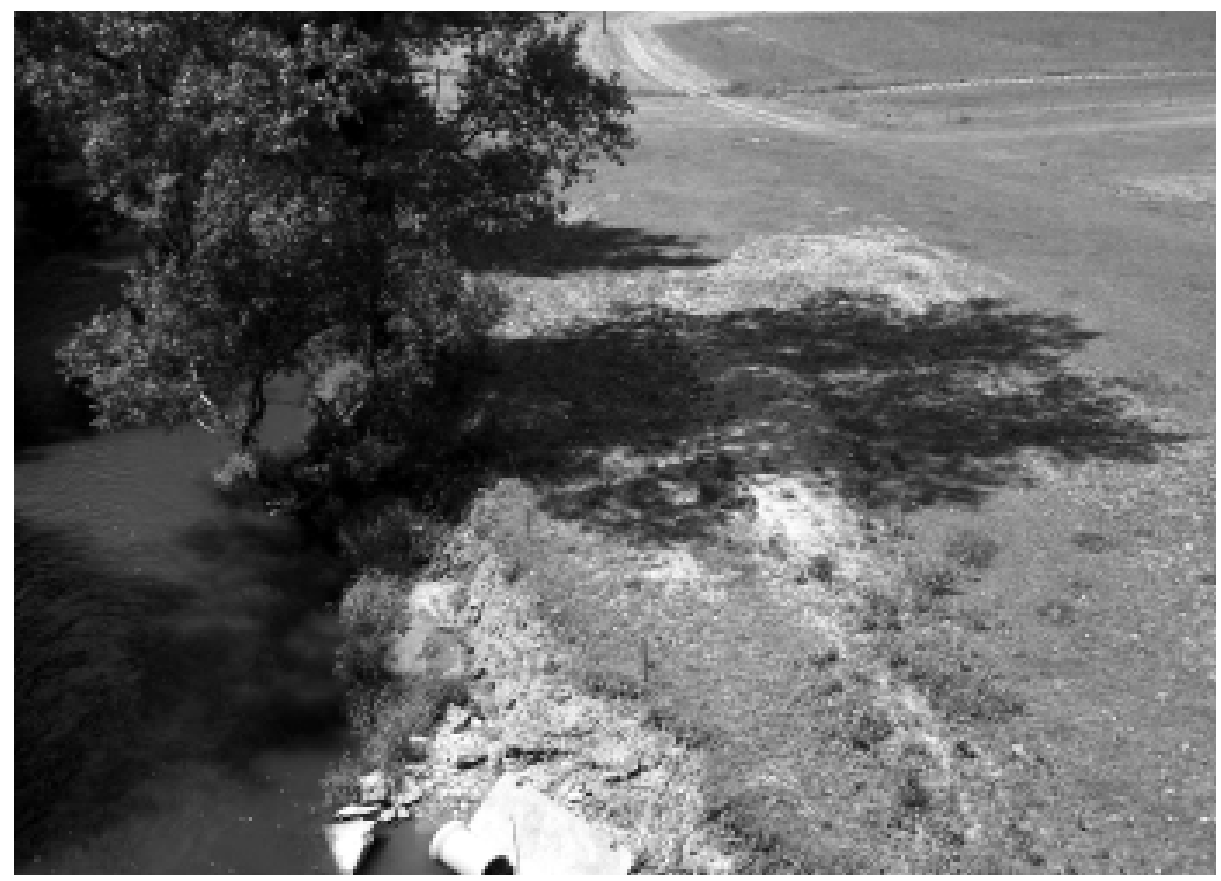

Fig. 8: The bank scour and flood overbank accumulation behind a bridge below Havlíčkův Brod. The bridge and its road create a transverse barrier in Sázava River floodplain

level overbuilding of the Sázava River floodplain reflected in little destructive effects of the spring flood and relatively small material damages caused by the flooding. Roads and railways and anthropogenic mounds connected to them have mainly direction parallel to the flow and they are situated by border of the floodplain. Permanently inhabited settlements are in large extend connected to old alluvial terraces, it means outside inundation zone. Also huts and cottages are located by borders of the floodplain and on alluvial fans which rise up inundation areas. Bridges as potential barriers of flowing water have in most cases sufficient reserve for higher water-level stage of Sázava River.

\section{Interpretation and discussion}

\section{Relations of fluvial accumulation landforms}

Narrowing of cross-section profile, actually bottom of floodplain, reflects also in rise of kinetic energy of flowing water and in rise of erosive force of river. When floodplain widens again the speed decreases and so does transport ability of river which reflects in higher rate of accumulation. The character of Sázava River valley with its noticeable variation of width of valley bottom (especially in its middle and upper parts 
of Sázava River) predisposed this river to "morphological" acceleration of stream speed. Exponential fall of flood overbank accumulations number depended on distance from channel of Sázava River (Fig. 3) corresponds to progress of decreasing sedimentation rate $\left(\mathrm{g} / \mathrm{cm}^{2} /\right.$ year) in five floodplains of rivers in England (Stour, Culm, Severn, Rother, Avon) (Welling, He, 1998). On the other hand, the flood on Sázava River does not belong to greater floods with respect to the progress of the relative amount of sedimentation in the flooded area (sensu Steiger, Gurnell, 2002). Proportionally higher representation of combined (coarser) flood overbank accumulations in bigger distances from the channel $(25-75 \mathrm{~m})$ can be explained by origin of these accumulations in areas with higher speed of bankfull flow which proves presence of coarse-grained material. Similar effect was described by Benedetti (2003) where the mean value of grain size of the 2001 flood deposits laying in the middle of McGregor Island was also greater than on its edge. While the flood went out, finegrained sediments deposited in bigger distances than coarser sediments (e.g. Pizzuto, 1987; Asselmann, Middelkoop, 1995; Walling et al., 1997). It corresponds to spatial position of combined accumulations in areas of floodplain narrowing or by a mouth of stream tributary. Thus combined accumulations can be found in places with appropriate conditions for acceleration of bankfull stream. These parts of floodplain with combined accumulations can be considered as potential areas of more considerable effects of fluvial processes connected to overbank stream and following accelerated geomorphologic consequences such as creation of new erosion furrows, braiding of overbank stream and overbank sedimentation. It corresponds to findings of Pierce and King (2008), which show that the mean sediment overbank deposition in these areas (shoal and valley plug sites) is $2-10$ times greater than at unchannelized sites.

Mutual communication between accumulation processes in the channel and floodplain of Sázava River proves dependency on spatial distribution of fluvial

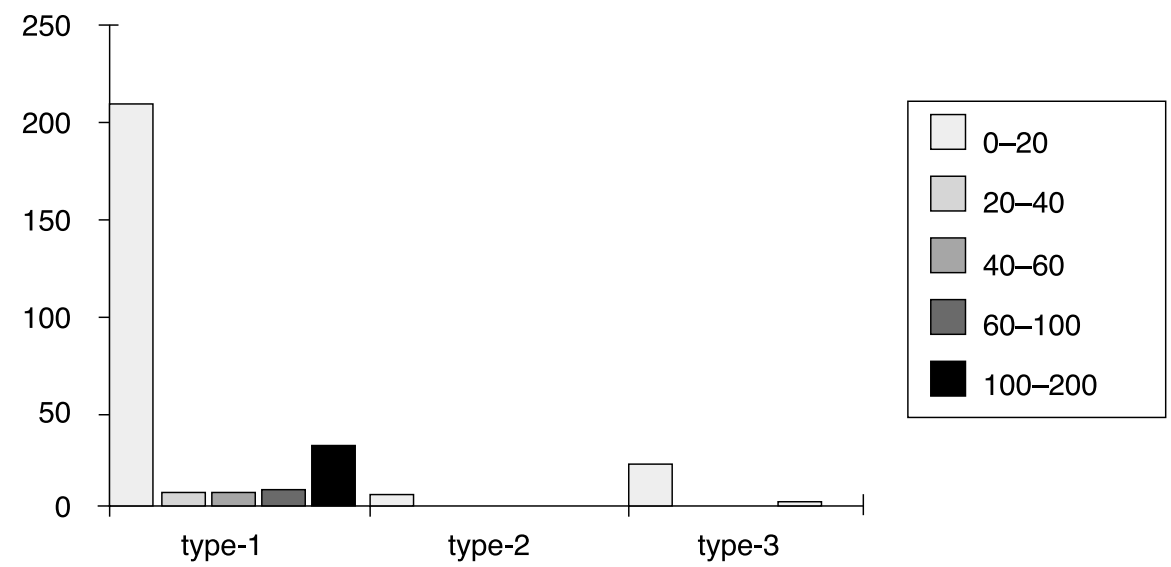

Fig. 9: Number of flood overbank accumulations according to type of sediment regarding distance from channel bars. Category values $0-30,30-50$ etc. represent distances (in meters) between channel bars and flood overbank accumulations of Sázava River. Type 1 - sandy flood accumulations, 2 - gravel-cobble flood accumulations, 3 - combined flood accumulations 


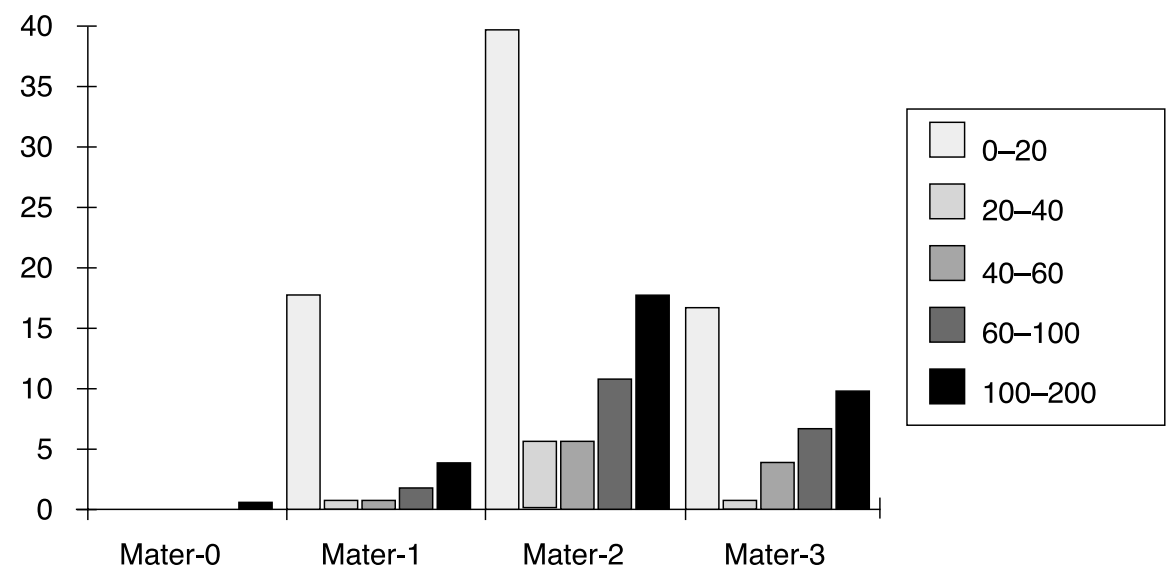

Fig. 10: Number of channel bars according to sediment type regarding distance from flood overbank accumulations. Category values 0-20, 20-40 etc. represent distances (in meters) between channel bars and flood accumulations in floodplain of Sázava River. Mater-0 ... non specified channel bars; Bars: Mater-1 ... sandy; Mater-2 ... gravel-cobble; Mater-3 ... combined

sediments in the area of the channel and its floodplain. 89\% of flood overbank accumulations of the floodplain are located within $20 \mathrm{~m}$ distance from channel bars (Fig. 9). On the contrary up to distance of $20 \mathrm{~m}$ from flood accumulations in floodplain there are 50\% of all channel bars (Fig. 10). This disproportion is caused by bigger spatial diffusion of flood overbank accumulations and by difference in number of channel bars (147) and flood overbank accumulations in the floodplain (303). Concerning distance characteristics we cannot forget that overvaluation of number of objects depending on increasing distance is caused by multiple count in of one object to greater distance categories. From the above mentioned it is clear that channel bars, which are more noticeable and can be mapped faster owing to their specific location, can be used for prediction of spatial distribution of flood accumulations in Sázava River floodplain. Thus, it is a simple method for predicting overbank deposition during floods with similar magnitude. Relationship between channel bars and flood overbank accumulations in the floodplain is determined by flood magnitude (Steiger, Gurnell, 2002) and it may not exist in great floods or it can be smaller because the maximum sedimentation might be expected to occur at the floodplain margins (Bridge, Leeder, 1979).

From the viewpoint of type of sediment it was proved that channel bars and flood accumulations in the floodplain have completely different grained composition (Fig. 11). This difference is statistically significant (it was tested by one-way ANOVA with current effect: $\mathrm{F}(1,448)=189.35, \mathrm{p}=0.0000)$. While channel bars have rather gravel-cobble character $(56 \%)$, flood accumulations of floodplain are sandy (88\%). It indicates different sedimentary conditions outside and inside the channel during the floods (also e.g. Steiger, Gurnell, 2002). It didn't significantly succeed to prove grain sizes equivalence between channel bar sediment and overbank sediment. Thus, type of flood overbank accumulation can not be estimated based on type of channel bars' sediment. 


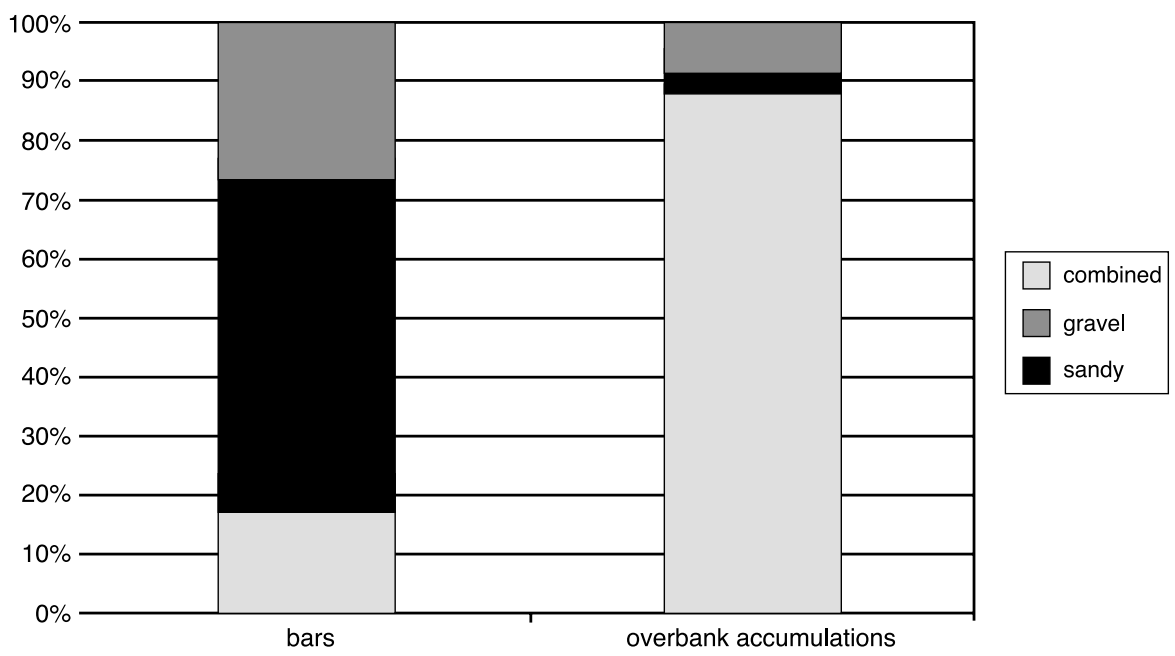

Fig. 11: Comparison of channel bars and flood overbank accumulations in floodplain according to sediment type

Analysis of bars' occurrence shows that they are concentrated in areas with lower sediment function of stream. Bends with abrupt change of stream direction, places under weirs and places near embouchure of adjacent river are these areas. Channel bars are created during floodings, actually at their end, and define places of higher rate of sediment deposition in the channel where they form potential barriers of the flow. It results in increased erosion activity and formation of bank scours. Thus, channel bars are also indicator of zones of higher erosion effectiveness of stream. On the other hand, this result reflects presence of weirs to which channel bars are connected. Weirs are places with greater sediment deposition and represent valley plugs in sense of Pierce and King (2008). Full-grown vegetation including self-seeding of shrubs and trees proves longlasting process of sedimentation in chosen locality (channel bars). The results show that vegetation is more or less resistant regarding existing weirs and is developed in channel bars evenly along the whole stream without dependence on distance from the weirs.

From the viewpoint of spatial distribution of channel bars regarding weirs, mainly of gravel-cobble and combined channel bars, we can say that weirs influence change of behavior of Sázava River (from the viewpoint of sedimentation) in distance of approximately $60 \mathrm{~m}$. Rapid decrease of stream energy proves occurrence of channel bars with normal gradation whose presence out of areas influenced by weirs is very low. On the contrary, channel bars without gradation are typical for parts of Sázava River which are not influenced directly by weirs, i.e. in distances bigger than $100 \mathrm{~m}$. More frequent occurrence of channel bars placed under weirs in the centre of the channel is caused by the fact that the channel is wider in these areas, that way larger islands of channel bars can be created. It follows that smaller channel bars connected to banks are typical for parts of Sázava River which are not influenced by direct impact of weir's steps. Zielinski (2003) showed that the central longitudinal bars were formed in straight flow of Nysa River. Thus, this type of channel bars is typical for mid-channel streamline. 
Bank scours bond flood overbank accumulations in floodplain (Fig. 12) and channel bars (Fig. 13) to themselves. $80 \%$ of all flood accumulations in floodplain are located up to $10 \mathrm{~m}$ from bank scours. All gravel-cobble and combined flood overbank accumulations in floodplain are located up to $10 \mathrm{~m}$ from bank scours. $83 \%$ of all bars are located up to $10 \mathrm{~m}$ from bank scours. Sedimentation occurs when ability of stream drifting lowers. It is related to speed change of water flowing in the channel (with lower friction) and in the floodplain (with higher friction) during flood (Bridge, 2003). This change of speed of stream is the biggest between the channel and the rest of the floodplain. That is why the biggest sedimentation and the most thick flood accumulations are located tightly by banks of floodplain (e.g. Walling, He, 1998; Benedetti, 2003). It shows also position of well transportable sandy flood accumulations (Fig. 12) regarding bank scours which line banks of the channel. Many flood overbank accumulations are the largest in immediate vicinity of channel. Then number of flood overbank accumulations decreases slowly in distance of $10-20 \mathrm{~m}$ from the midstream of channel and in distance of 20-50 m from the channel midstream it has an increasing tendency which is caused probably by sedimentation of material from damaged nearby bank. It correlates with a conceptual model of riparian sedimentation patterns - type (b): sedimentation pattern generated by a larger flood within a geomorphologically simple and constrained setting (Steiger, Gurell, 2002).

Weirs in period of time of high water level are potential places of stream instability and cause significant changes of behavior of this stream. Noticeable relation effects of fluvial lateral erosion and origin of bank scours in their vicinity proves that.

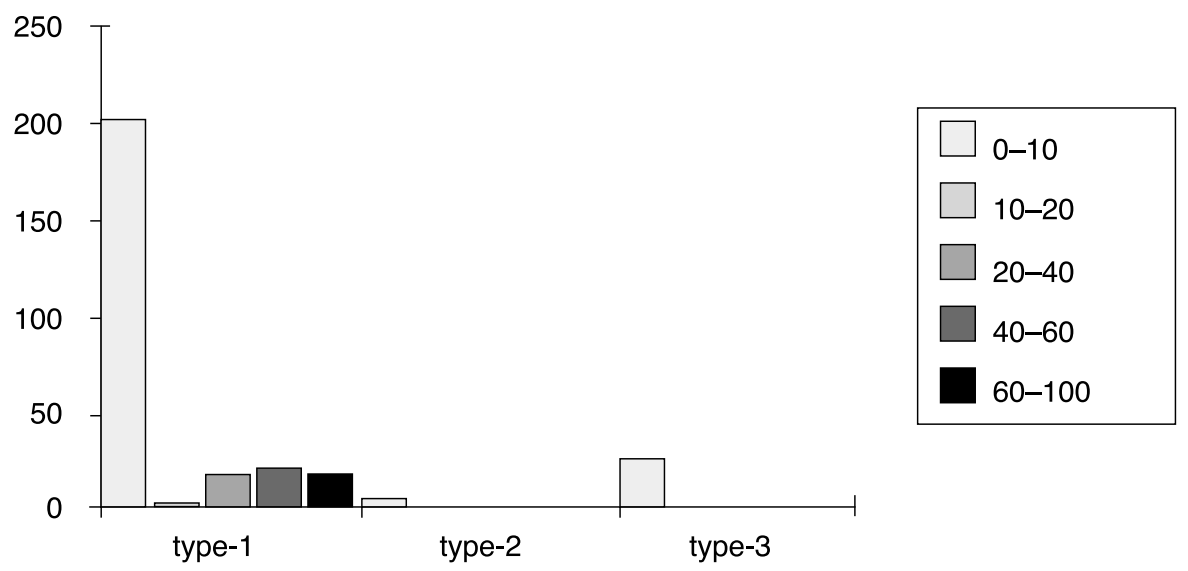

Fig. 12: Number of flood overbank accumulations in floodplain by type of sediment regarding distance from bank scours. Category values 0-10, 10-20 etc. represent distances (in meters) between overbank accumulations of Sázava River and bank scours. Type 1 - sandy flood accumulations, 2 - gravel-cobble flood accumulations, 3 - combined flood accumulations 


\section{Conclusion}

Despite the spring flood in Sázava River caused inundation of the whole floodplain and in some places crossed its border, its consequences were not as serious as in streams in river basin Otava after summer flooding in 2002 (Kř́žek, Engel, 2006). It is mostly caused by small build over of floodplain of Sázava River and its channel. In spite of this some anthropogenic impacts in the floodplain and channel of Sázava River represent potential risks of overbank of stream which bond accelerated erosion and accumulation. It concerns mainly weirs.

During the spring flood in 2006 fluvial accumulation processes prevailed over erosion. It turned out that places with the highest number of flood overbank accumulations in floodplain agree with places with the greatest occurrence of flood overbank accumulations in the floodplain. Number of flood overbank accumulations falls exponentially with increasing distance from the river channel (Fig. 13). Proportionally higher representation of combined (coarser) flood overbank accumulations in bigger distances from the channel (25-75 m) can be explained by origin of these accumulations in areas of higher speed of bankfull flow which proves presence of coarse-grained material. Benedetti (2003) also described a similar rise of grain size depending on distance from the channel. Spatial distribution of channel bars, flood overbank accumulations in floodplain and bank scours is uneven and significantly connected to weirs.

Channel bars are a good typical feature of sedimentary activity of stream. Channel bars are connected to weirs whose immediate effective sedimentary activity reaches in Sázava River to distance up to $60 \mathrm{~m}$. Smaller channel bars connected to banks are typical for parts of river which are not influenced by weirs. Channel bars also have close connection with deposition of flood accumulations within floodplain (89\% of flood accumulations in floodplain are located up to $20 \mathrm{~m}$ from a channel bar) and with spatial distribution of bank scours. Channel bars

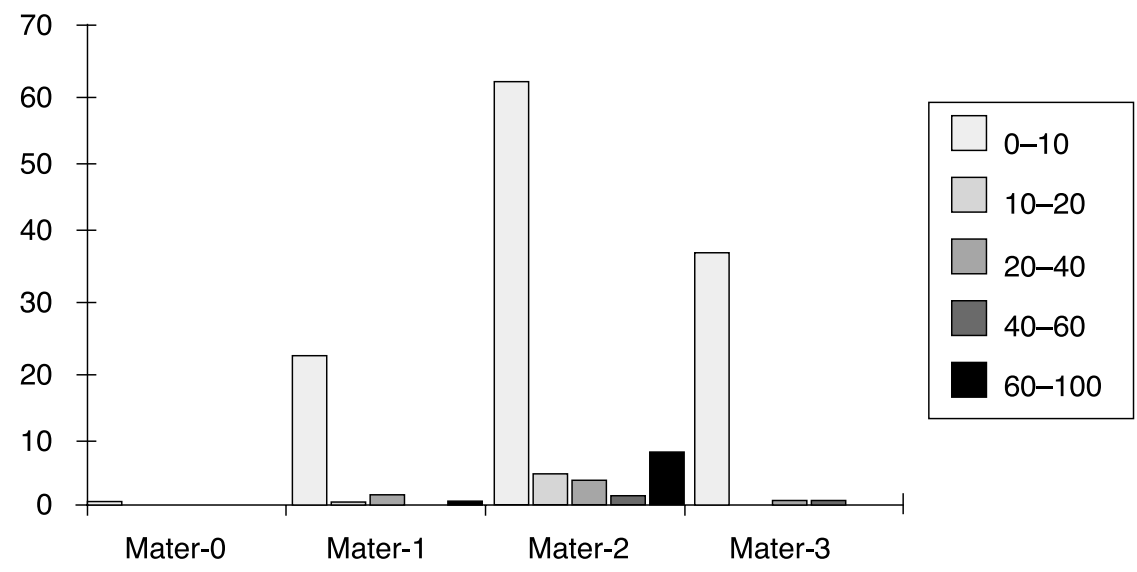

Fig. 13: Number of channel bars by type of sediment regarding distance from bank scours. Category values $0-10,10-20$ etc. represent distances (in meters) between channel bars and bank scours. Mater- 0 ... non specified channel bars; Bars: Mater-1 ... sandy; Mater-2 ... gravel-cobble; Mater-3 ... combined 
can be used for prediction of higher accumulation activity occurrence in floodplain but it can not be used for prediction of sedimentation type. Combined flood overbank accumulations in floodplain are concentrated to places with multiple flood sedimentation and they support areas of floodplain which are more endangered by geomorphologic features of flood.

\section{Acknowledgements}

This contribution was financially supported by MŽP ČR (Ministry of Environment of the Czech Republic), project $\mathrm{VaV}$ SM/2/57/05 "Long-term changes in fluvial ecosystems in floodplains affected by extreme floods" and research project "Geographical Systems and Risk Processes in the Context of Global Changes and European Integration” (MSM 0021620831). Special thanks for field mapping of geomorphological consequences of flood to Klára Vočadlová, Jan Kavan, Tomáš Chuman, Václav Treml, Hana Baláková, Václav Vajskebr, Dušan Romportl.

\section{Literature}

ASSELMANN, N.E.M., MIDDELKOOP, H. (1995): Floodplain sedimentation: quantities, patterns and processes. Earth Surface Processes and Landforms, 20, pp. 481-489.

BALATKA, B., SLÁDEK, J. (1962): Říční terasy v českých zemích. ČSAV, Praha, 578 p.

BENEDETTI, M. M. (2003): Controls on overbank deposition in the Upper Mississippi River. Geomorphology, 56, pp. 271-290.

BRIERLEY, G.J., FRYIRS, K.A. (2005): Geomorphology and river management. Blackwell, Oxford, $398 \mathrm{p}$.

BRIDGE, J.S. (2003): Rivers and floodplains. Blackwell, Oxford, 491 p.

BRIDGE, J.S., LEEDER, M.R. (1979): A simulation model of alluvial stratigraphy. Sedimentology, 26, pp. 617-644.

COLLIN, P.H. (1988): Dictionary of Ecology and the Environment. Teddington Park, Peter Collin Publishing, $198 \mathrm{p}$.

HICKIN, E.J. (1983): River channel changes, retrospect and prospect. - In: Collinson, J.D., and Lewin, J., (eds.): Modern and ancient fluvial systems: International Association of Sedimentologists Special Publication 6, pp. 61-83.

HRÁDEK, M. (1999): Geomorphological aspects of the flood of July 1997 in the Morava and Oder basins in Moravia, Czech Republic. Studia Geomorphologica Carpatho-Balcanica, 33, pp. 45-46.

HRÁDEK, M. (2005): Changes in the channels and floodplains of Sudetic rivers in the Morava river basin after the flood in July 1997. - In: A. Szponar and S. Horska-Schwarz (eds.): The spatial-functional structure of landscape. The problems of landscape ecology. Wróclaw: Polish association for landscape ekology, Vol. XVII, pp. 226-231.

HOOKE, J. (2003): Coarse sediment connectivity in river channel systems: a conceptual framework and methodology. Geomorphology, 56, pp. 79-94.

HUGGETT, R.J. (2003): Fundamentals of geomorphology. Routledge, London, 408 p.

KNIGHTON, A.D. (1998): Fluvial forms and processes: A new perspective. Arnold, London, 383 p.

KOSTER, E.H. (1978): Transverse ribs; their characteristics, origin and palaeohydraulic significance. Memoir - Canadian Society of Petroleum Geologist 5, pp. 161-186.

KŘÍŽEK, M. (2006): Geomorfologické projevy jarní povodně 2006 na Sázavě. - In: Langhammer, J. (ed.): Dlouhodobé změny pořičních ekosystémů v nivách toků postižených extrémními záplavami. Dílčí zpráva projektu VaV SM/2/57/05, Přf UK, Praha: Přf UK, pp. 102-123. 
KŘİŽEK, M., ENGEL, Z. (2006): Geomorphological Consequences of the 2002 Flood in the Otava River Drainage Basin. Acta Universitatis Carolinae - Geographica, 38, 2, pp. 125-138.

KŘížEK, M., HARTVICH, F., CHUMAN, T., ŠEFRNA, L., ŠOBR, M., ZÁDOROVÁ, T. (2006): Floodplain and it delimitation. Geografie, 111, 3, pp. 260-273.

KŘÍŽEK, M. (2007a): Údolní niva jako geomorfologický fenomén. - In: Langhammer, J. (ed.): Povodně a změny v krajině, Praha: P3K, pp. 217-229.

KŘ́̌Ž̌EK, M. (2007b): Prostorové uspořádání popovodňových korytových akumulací Sázavy. - In: Langhammer, J. (ed.): Změny v krajině a povodňové riziko, Praha: Přf UK, pp. 153-161.

KUKAL, Z. (1985): Návod k pojmenování a klasifikaci sedimentů. ÚÚG, Praha, 80 p.

LEHOTSKÝ, M. (2005): Metodologické aspekty správania a zmien korytovo-nivných geosystémov. Geomorfologia Slovaca, 1, pp. 34-50.

PIERCE, A.R., KING, S.L. (2008): Spatial dynamics of overbank sedimentation in floodplain systems. Geomorphology, 100, pp. 256-268.

PIZZUTO, J.E. (1987): Sediment diffusion during overbank flows. Sedimentology, 34, pp. 301-317.

SHUMM, S.A., THORNE, C.R. (1989): Geologic and geomorphic controls on bank erosion. - In: Ports, M.A. (ed.): Hydraulic Engineering, New York: Proceedings of the American Society of Civil Engineers, pp. 106-111.

STEIGER, J., GURNELL, A.M. (2002): Spatial hydrogeomorphological influences on sediment and nutrient deposition in riparian zones: observations from the Garonne River, France. Geomorphology, 49, pp. 1-23.

ŠERCL, P. et al. (2006): Hydrologické vyhodnocení jarní povodně 2006 na území ČR. In: - Kašpárek, L. (ed.): Meteorologické a hydrologické vyhodnocení jarní povodně 2006 na území ČR, Praha: VÚV a ČHMÚ, pp. B1-B22.

WALLING, D.E., OWENS, P.N., LEEKS, G.J.L. (1997): the characteristics of overbank deposits associated with a major flood event in the catchment of the River Ouse Yorkshire, UK. Catena, 31, pp. 53-75.

WALLING, D.E., HE, Q. (1998): The spatial variability of overbank sedimentation on river floodplains. Geomorphology, 24, pp. 209-223.

WHITTOW, J. (1984): Dictionary of Physical Geography. The Penguin, Oxford, 591 p.

ZIELINSKI, T. (2003): Catastrophic flood effects in alpine/foothill fluvial system (a case study from the Sudetes Mts, SW Poland). Geomorphology, 54, pp. 293-306.

Résumé

Prostorové rozmístění erozních a akumulačních fluviálních tvarů na Sázavě po povodni 2006

Předložený článek pojednává o korytových akumulacích, povodňových akumulacích údolní nivy a břehových nátržích jako nejdủležitějších geomorfologických projevech jarní povodně na Sázavě v roce 2006. Zvláště pak si všímá jejich prostorového rozmístění vzhledem ke korytu, jezům a sobě navzájem. Je zkoumán vztah mezi základními sedimentologickými charakteristikami těchto korytových akumulací, jejich rozmístěním a polohou vzhledem $\mathrm{k}$ jezům.

Problematika akumulace $\mathrm{v}$ údolní nivě je řešena $\mathrm{v}$ zahraničí pomocí analýzy přírůstu sedimentů, např̀ Nicholas and Walling (1997), Walling and He (1998), Steiger and Gurnell (2001), přičemž se autoři snaži pomoci svých výsledků predikovat ohrožená místa v přičném profilu údolních niv. Výhodou takovéhoto př́stupu je, že lze pozorovat $\mathrm{v}$ jednom místě několik sledů povodní. Nevýhodou je však, že u starých povodní se neví, jak patřičná část nivy vypadala, např. kudy vedlo koryto, což je zásadní pro distribuci sedimentů. V Čechách a na Slovensku převažuji na toto téma většinou práce popisné bez statisticky podložených zobecnění.

Během jarního období 2006 došlo k tání sněhu na velkých plochách stř̌edních poloh, což vedlo k rozvodnění velkého množství řek a následným povodním. 20. 3. 2006 činily celkové zásoby vody ve sněhové pokrývce v celém povodí Sázavy 446,3 mil. $\mathrm{m}^{3}$ (Šercl et al., 2006). Dvouvrcholová povodeň kulminovala 30. 3. 2006 a maximální průtok Sázavy v Nespekách byl $536 \mathrm{~m}^{3} / \mathrm{s}$, pro srovnání průměrný roční průtok Sázavy v Nespekách je $23,4 \mathrm{~m}^{3} / \mathrm{s}$ (Šercl et al., 2006). 
Přestože jarní povodeň na Sázavě způsobila zaplavení celé údolní nivy a místy překročila i její hranici, nebyly její následky takové jako na vodních tocích povodí Otavy po letních povodních v roce 2002 (Křǐžek, Engel 2006). Z velké míry je to dáno menším zastavěním údolní nivy Sázavy a jejího koryta. Přesto však některé antropogenní zásahy do údolní nivy a koryta Sázavy představují potenciální rizika $\mathrm{v}$ případech vybřežení vodního toku, které na sebe váží akcelerovanou erozi a akumulaci. Jedná se zejména o jezy.

Během jarní povodně 2006 převládaly v údolní nivě Sázavy akumulační fluviální procesy nad erozními. Ukázalo se, že místa s největším počtem povodňových akumulací v údolní nivě mimo koryto se shodují s místy výskytu nejrozlehlejších mimokorytových povodňových akumulací. Rozmístění korytových akumulací, povodňových akumulací údolní nivy a břehových nátrží je nerovnoměrné a značně vázané na jezy.

Exponenciální pokles množství mimokorytových povodňových akumulací se vzdáleností od koryta Sázavy (obr. 3) odpovídá průběhu poklesu sedimentační rychlosti ( $\left.\mathrm{g} / \mathrm{cm}^{2} / \mathrm{rok}\right)$, podobně jak to bylo zjištěno v údolních nivách anglických řek (Welling, He, 1998). Poměrově větší zastoupení kombinovaných (hrubozrnějších) mimokorytových povodňových akumulací ve větších vzdálenostech od koryta 25-75 m je možné vysvětlit vyšší rychlostí vybřeženého vodního toku v této zóně, což dokládá i přítomnost hrubozrnějšího materiálu v této zóně. Podobný nárůst zrnitosti od koryta popisuje i Benedetti (2003).

Korytové akumulace jsou dobrým charakteristickým znakem sedimentační činnosti vodního toku. Korytové akumulace jsou vázány na jezy, jejichž bezprostřední efektivní sedimentační působnost zasahuje na Sázavě do vzdálenosti 60 metrů. Menší korytové akumulace spojené se břehy jsou typické pro části toku, které nejsou ovlivněné jezy. Stejně tak mají korytové akumulace těsnou souvislost s ukládáním povodňových akumulací v rámci údolní nivy ( $89 \%$ povodňových akumulací údolní nivy se nachází do vzdálenosti 20 m od korytové akumulace) a s rozmístěním břehových nátrží. Korytové akumulace lze u povodní podobného rozsahu použít při predikci výskytu zvýšené akumulační činnosti v údolní nivě, avšak nelze ji využít z hlediska predikce typu sedimentace. Zde je třeba připomenout, že síla vazby mezi korytovými akumulacemi a povodňovými akumulacemi v údolní nivě je ovlivněna magnitudem povodně (sensu Steiger, Gurnell, 2002), s tím, že u velkých povodní nemusí vzájemná podmíněnost existovat a nebo může být menší, nebot maximum sedimentace může být v takových případech lokalizováno do okrajů údolní nivy (Bridge, Leeder, 1979).

Kombinované povodňové akumulace v nivě jsou soustředěny do míst s vícenásobnou povodňovou sedimentací a dokumentují ta místa nivy, která jsou více ohrožena geomorfologickými projevy povodní.

Obr. 1: Studované území.

Obr. 2: Hustota fluviálních povodňových akumulací v údolní nivě. Hustota udává počet fluviálních akumulací na $1 \mathrm{~km}^{2}$ pro rádius $1000 \mathrm{~m}$. A - každá mimokorytová povodňová akumulace je reprezentována polohou těžiště. B - každá mimokorytová povodňová akumulace je reprezentována sítí bodů, jejichž počet je vážen velikostí příslušného akumulačního tvaru.

Obr. 3: Poměrné zastoupení jednotlivých typů fluviálních akumulací vzhledem ke vzdálenosti od koryta (stř̌ednice vodního toku). Type 1 - jsou hlinitopísčité fluviální akumulace, 2 - štěrkovokamenité fluviální akumulace, 3 - kombinované fluviální akumulace. Kategorizační hodnoty, 0-25, 25-50, atd. představují vzdálenosti v metrech od střednice vodního toku.

Obr. 4: Hustota korytových akumulací na Sázavě. Hustota udává počet fluviálních akumulací na $1 \mathrm{~km}^{2}$ pro rádius $1000 \mathrm{~m}$.

Obr. 5: Rozmístění korytových akumulací vzhledem ke vzdálenosti od jezů (v metrech). Mater-0 ... nespecifikované korytové akumulace; Korytové akumulace: Mater-1 ... hlinitopísčité; Mater-2 ... štěrkovokamenité; Mater-3 ... kombinované.

Obr. 6: Korytová akumulace pokrytá travou pod jezem u Chřenovic.

Obr. 7: Hustota břehových nátrží na Sázavě. Hustota udává počet břehových nátrží na 1 km² pro rádius $1000 \mathrm{~m}$. Obr. 8: Břehová nátrž a fluviální akumulace v údolní nivě za mostem pod Havlíčkovým Brodem. Most a nájezd na něj působí jako příčná překážka v údolní nivě Sázavy. Na fotografii je patrná trasa proudění vybřežené Sázavy.

Obr. 9: Zastoupení mimokorytových povodňových akumulací údolní nivy dle typu sedimentu vzhledem ke vzdálenosti od korytových akumulací. Kategorizační hodnoty, 0-30, 30-50, atd. představují vzdálenosti v metrech mezi akumulacemi v korytě a mimo koryto. Type 1 - jsou hlinitopísčité fluviální akumulace, 2 - štěrkovokamenité fluviální akumulace, 3 - kombinované fluviální akumulace.

Obr. 10: Zastoupení korytových akumulací dle typu sedimentu vzhledem ke vzdálenosti od mimokorytových povodňových akumulací údolní nivy. Kategorizační hodnoty, 0-30, 30-50, atd. představují vzdálenosti 
v metrech mezi akumulacemi v korytě a mimo koryto. Mater- 0 ... nespecifikované korytové akumulace; Korytové akumulace: Mater-1 ... hlinitopísčité; Mater-2 ... štěrkovokamenité; Mater-3 ... kombinované.

Obr. 11: Srovnání korytových akumulací a povodňových mimokorytových akumulací údolní nivy z hlediska typu sedimentů.

Obr. 12: Počet mimokorytových povodňových akumulací údolní nivy dle typu sedimentu vzhledem ke vzdálenosti od břehových nátrží. Kategorizační hodnoty, 0-10, 10-20, atd. představují vzdálenosti v metrech mezi mimokorytovými akumulacemi v údolní nivě Sázavy a břehovými nátržemi. Type 1 - jsou hlinitopísčité fluviální akumulace, 2 - štěrkovokamenité fluviální akumulace, 3 - kombinované fluviální akumulace. Obr. 13: Počet korytových akumulací dle typu sedimentu vzhledem ke vzdálenosti od břehových nátrží. Kategorizační hodnoty, 0-10,10-20, atd. představují vzdálenosti v metrech mezi korytovými akumulacemi a břehovými nátržemi. Mater-0 ... nespecifikované korytové akumulace; Korytové akumulace: Mater-1 ... hlinitopísčité; Mater-2 ... štěrkovokamenité; Mater-3 ... kombinované.

Tab. 1: Zjištované charakteristiky vybraných tvarů při mapování geomorfologických následků jarní povodně 2006 na Sázavě.

Marek Kř̌̌žek

Charles University in Prague

Faculty of Science, Department of Physical Geography and Geoecology

Albertov 6

12843 Prague 2

Czech Republic

e-mail:krizekma@natur.cuni.cz 